\title{
ОНТОЛОГІЧНА МОДЕЛЬ ПРОЦЕСІВ ПРОГРАМОВАНОЇ КЛІТИННОЇ ЗАГИБЕЛІ
}

\author{
О. П. Мінцер, Д. В. Ватліцов \\ Національна медична академія післядипломної освіти імені П. Л. Шупика
}

\begin{abstract}
Структурною одиницею життя на землі є клітина. Важливим аспектом існування клітини, як одиниці життя, є їі здатність до елімінації нежиттєздатних або дефектних одиниць з системи без пошкодження інших одиниць. Проведені дослідження виявили зростання кількості робіт, присвячених системним дослідженням програмованої клітинної загибелі. Виходячи з результатів проведеного аналізу літературних джерел фрормалізовано схему та описано рівні організації, на яких можливе виникнення «події», яка ініціює каскади, що призводять до настання ПКЗ. Також було виявлено основні напрямки розвитку досліджень, переважна кількість котрих охоплюють рівні вище молекулярної взаємодії, згідно з запропонованою нами онтологічною моделлю програмованої клітинної загибелі. Виявлено біфуркаційну природу проходження сигналу ПКЗ та окреслено роль компонентів, віднесених нами до рівнів нижче молекулярної взаємодії. На основі цих даних запропоновано маркери розвитку та способи управління процесами ПКЗ через контроль концентрації іонів промоутерів та інгібіторів. Результати даного дослідження $є$ підґрунтям для системного вивчення шляхів виникнення, розвитку та управління активного каскаду ПКЗ.
\end{abstract}

Ключові слова: системна біологія, програмована клітинна загибель, подія, тригер, онтологічна модель.

\section{ОНТОЛОГИЧЕСКАЯ МОДЕЛЬ ПРОЦЕССОВ ПРОГРАММИРОВАННОЙ КЛЕТОЧНОЙ ГИБЕЛИ}

\author{
О. П. Минцер, Д. В. Ватлицов \\ Национальная медицинская академия последипломного образования имени П. Л. Шупика
}

\begin{abstract}
Структурной единицей жизни на земле является клетка. Важным аспектом существования клетки, как единицы жизни, является ее способность к элиминации нежизнеспособных или дефектных единиц из системы без повреждения других единиц. Проведенные исследования выявили рост количества работ, посвященных системным исследованиям программированной клеточной гибели (ПКГ). Исходя из результатов проведенного анализа литературных источников, формализована схема и описаны уровни организации, на которых возможно возникновение «события», инициирующего каскады, приводящие к наступлению ПКГ. Также было выявлено основные направления развития исследований, подавляющее количество которых охватывают уровни выше молекулярного взаимодействия, согласно предложенной нами онтологической модели программируемой клеточной гибели. Выявлено бифуркационную природу прохождения сигнала ПКГ и обозначены роли компонентов, которые были отнесены нами к уровням ниже молекулярного взаимодействия. На основе этих данных предложены маркеры развития и способы управления процессами ПКГ через контроль концентрации ионов промоутеров и ингибиторов. Результаты данного исследования являются основой для системного изучения путей возникновения, развития и управления активного каскада ПКГ.
\end{abstract}

Ключевые слова: системная биология, программированная клеточная гибель, событие, триггер, онтологическая модель.

\section{THE ONTOLOGICAL MODEL OF THE PROCESSES OF PROGRAMMED CELL DEATH}

\author{
O. P Mintser, D. V. Vatlitsov \\ Shupyk National Medical Academy of Postgraduate Education
}

The structural unit of the life on earth is a cell. An important aspect of the existence of cells, as a unit of life, is its capacity for elimination of non-viable or defective units from the system without damage of other units. Studies have revealed growth of the number of papers devoted to systematic research of the programmed cell death (PCD). Based on the results of the analysis of literary sources, the scheme of the levels of «events» which initiates a cascade of the PCD was formalized also the levels were described. The main directions of research was revealed, the overwhelming number of 
which include the investigations in which were developed the levels higher than level of molecular interaction, according to our proposed ontological model of programmed cell death. We had found the bifurcational nature of the signal chain of PCD and had investigated the role of components that had been assigned by us to levels lower than the level of molecular interaction. Based on these data, we proposed the concentration of ions promoters and inhibitors of PCD as a marker of development and control of programmed cells' death processes. The results of this research are the basis for the systematic study of ways to the origin, development and management of the active cascade of programmed cell death.

Key words: system biology, programmed cell death, events, trigger, ontological model.

Вступ. Процеси, що відбуваються у клітині, як одиниці життя наземлі, безпосередньо залежать від умов навколишнього середовища. Впродовж мільйонів років еволюції клітина пристосувалася до стаціонарних умов навколишнього середовища. У ході еволюційних процесів вона віднайшла потужні компенсаторні механізми, які дають можливість адаптуватися практично до будь-яких умов на землі $[1,2]$. Проте існуючий діапазон факторів навколишнього середовища дуже вузький, це пов'язано з тим, що «зона життя» вуглецевих форм обмежена, що, в свою чергу, пов'язано зі стійкістю біомолекул на основі вуглецю. Мінеральний склад ареалу проживання живих організмів також значною мірою однорідний, а це $є$ першопричиною того, що незначні коливання фізико-хімічних параметрів середовища проживання живого організму можуть призвести до смерті [37]. Еволюційно було визначено, що смерть одного живого організму системи не повинна призводити до летальних пошкоджень одиниць життя даної популяції, що і стало запорукою успішного виживання та еволюційної адаптації.

Важливим аспектом існування клітини, як одиниці життя, є програмована клітинна загибель (ПКЗ), яка $\epsilon$ основою виведення нежиттєздатних або дефектних клітин з системи $[8,9]$. На сьогодні гостро стоїть проблема регуляції ПКЗ, оскільки можливість регуляції процесів ПКЗ дозволить вирішити практично будь-які проблеми якісного існування живих систем: медичні, біотехнологічні, мікробіологічні, проблеми 3 продуктами харчування та інші, пов'язані з живими організмами. На сучасному етапі розвитку науки накопичені колосальні об'єми інформації про клітину [10], субклітинні структури, макромолекули і їх ланцюги взаємодії, молекулярний і елементний склад клітини [11], розшифрований геном людини [12], в повсякденному житті досліджується експресія генів за допомогою гібрид омних матриць [13]. Все викладене вище вказує на наявність глобальної проблеми упорядкування наявних даних і опису процесів взаємодії структурних субодиниць живої системи, що дозволить виявляти способи управління.

Мета роботи: формування гіпотези виникнення «подій», що призводять до настання програмованої клітинної загибелі, на різних рівнях організації живої системи (клітини). При цьому під «подією» (як і в теорії ймовірності) будемо розуміти будь-яке явища або експеримент, що впливає на систему і змінює їі функції.

У відповідності з метою досліджень, що проводяться, були сформульовані концептуальні завдання аналізу даних літератури:

1. Формалізувати умови здійснення програмованої клітинної загибелі.

2. Виявити і охарактеризувати способи передачі і міжрівневого управління сигналом ПКЗ.

3. Оцінити ступінь впливу «подій», що виникають на рівнях з меншою організацією, на рівні з високою організацією.

4. Розробити способи виявлення, контролю та управління сигналом ПКЗ.

Матеріали та методи дослідження. Стратегія пошуку літератури і аналіз вибудувані згідно з раніше опублікованими рекомендаціями [14]. Публікації відбирали за релевантністю згідно з пошуковими запитами 1) «програмована клітинна загибель» i «системна біологія»; 2) «іони металів» і «програмована клітинна загибель»; 3) назви іонів згідно 3 таблицею 1 і «системна біологія» $\mathrm{i}$ «програмована клітинна загибель» в пошуковій системі PubMed. Публікації на всіх мовах, опубліковані в рецензованих журналах. Пошук проводився за період 10 років (з січня 2005 року по березень 2015 року) було виявлено 3346 публікацій. Резюме всіх публікацій були досліджені на наявність необхідної інформації. Застосовували формалізований метод вивчення текстової та графічної інформації - контент-аналіз [15]. Також використовували метод об'єднання, зіставлення і вивчення даних згідно 3 пошуковими запитами, заснованими на поняттях, близьких за змістом до вихідних, що включав висновки як дослідника, так і інформанта - коллокейт аналіз [16].

Першим етапом було формування гіпотези визначення рівнів організації, на яких можливе виникнення «події», яка ініціює каскади, що призводять до настання ПКЗ. Запропоновано такі рівні організації «подій» (рис. 1): 


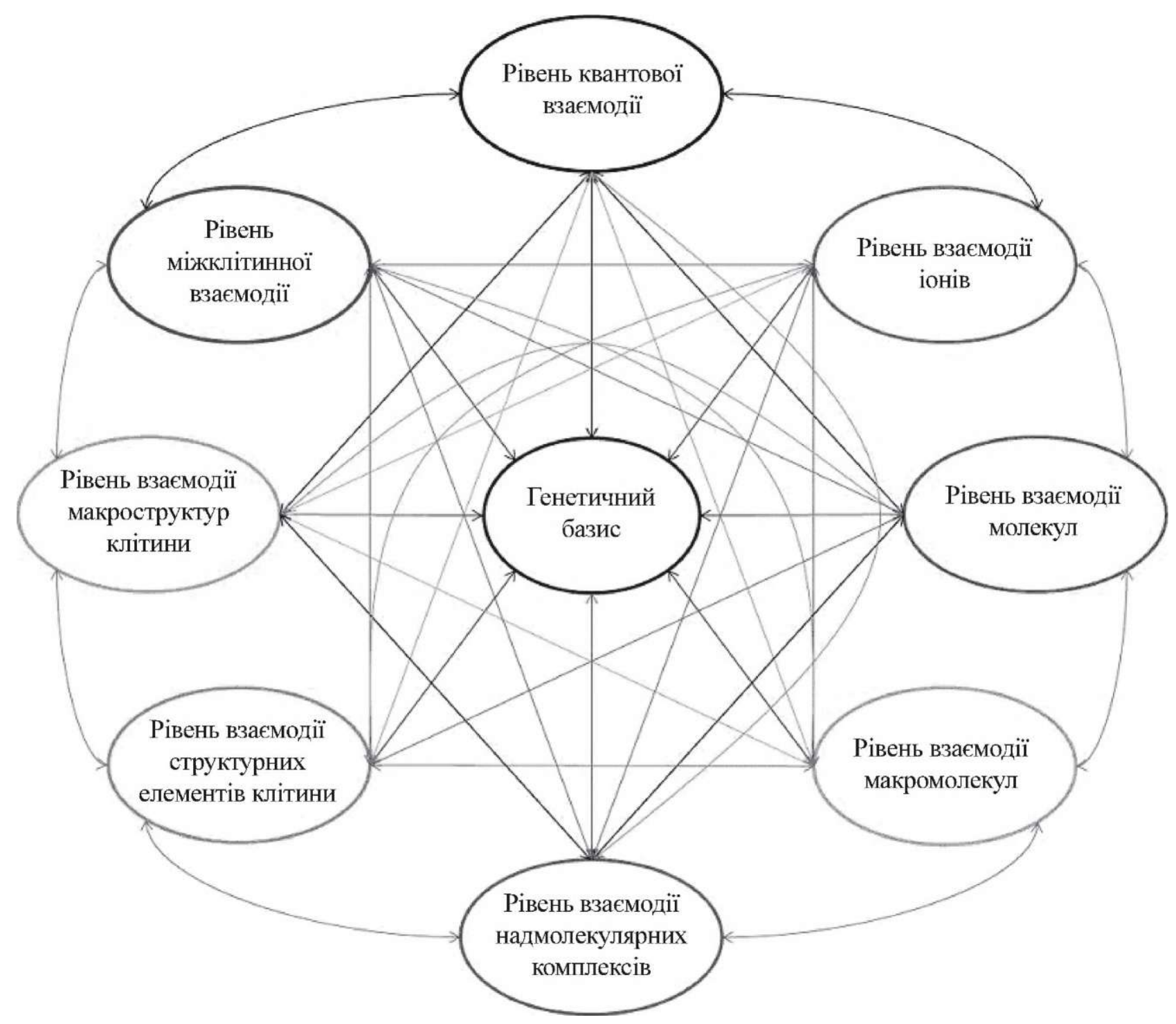

Puc. 1. Формалізація і управління міжрівневпмп процесами програмованої клітинної загибелі.

Обмеживши «події» певного характеру рівнем організації ми отримуємо можливість охарактеризувати спільність внеску та ступінь впливу кожної групи «подій» на процес ініціації каскаду реакцій, що призводять до ПКЗ, а також визначити ступінь впливу «подій» певного рівня на «події» інших рівнів організації. Важливим чинником настання ПКЗ є варіативність походження даної «події» і впливу інших компонентів системи.

Раніше було запропоновано використовувати «критерій доцільності», що дозволяє виділяти «події», які призводять, або з великою ймовірністю призведуть до запуску каскаду реакцій до настання ПКЗ. Важливим фактором $\epsilon$ коефіцієнт варіації «події», який використовується для визначення «критерію доцільності» [17].
Розглядаючи кожен рівень організації окремо варто враховувати кількість можливих комбінацій, довгі ланцюги передачі сигналу та наявність точок обриву сигналу, що впливає на «коефіцієнт варіації».

Рівень квантової взаємодії. Іонізуюче випромінювання. Як відомо, до іонізуючого випромінювання належить короткохвильове електромагнітне випромінювання високих енергій: космічні промені, реліктове випромінювання, рентгенівські промені; гамма-промені; УФ-випромінювання [18]. Найчастіше зустрічаються на Землі останні три, оскільки існують як природні, так і штучні джерела випромінювання [19]. Також до іонізуючих типів випромінювань відносять потоки частинок: бета-частинок; альфа-частинок; нейтронів; уламків поділу; протонів та інших іонів, мюонів тощо, але у зв'яз- 
ку $з$ тим, що дані види випромінювання на клітинному рівні наносять нерепаруємі ушкодження, які призводять до розвитку неконтрольованих процесів руйнування клітин [20-24], розглядати їх в даній роботі не будемо.

Існують теорії щодо «гормезісних» ефектів іонізуючого випромінювання в малих дозах [25,26], при тому що поняття «малі дози» не має чітких меж. Незаперечним є той факт, що іонізуюча радіація призводить до незворотних наслідків: дво- та одноланцюгові розриви ДНК, пошкодження білкових i клітинних структур, як пряме, так і опосередковане, через формування вільних радикалів [27].

Таким чином, сумарна дія іонізуючої радіації призводить до втрати проліферативної здатності i, як наслідок, до клітинної загибелі шляхом апоптозу чи некрозу [28]. Мішенню потоку високоенергетичних фотонів може бути будь яка клітинна структура чи молекула. Перевищення певної дози опромінення призводить до накопичення незворотних ушкоджень і загибелі клітини шляхом некрозу, але допорогові дози можуть активувати як репаративні процеси, так i ініціювати каскад реакцій ПКЗ. Так було показано, що іонізуюча радіація активує сигнальний шлях не тільки в ядрі, в результаті пошкодження ДІЖ і активації комплексів MRN і TIP60/ATM, а й на рівні плазматичних мембран, пошкоджень комплексів протеїнів, залучених до репарації ДНК (PARP) ДНК-залежних протеїнкіназ, p53 і АТМ, зовнішньоядерних сигнальних молекул (SAPK/JNK; протеїнкіназа C, цераміди і активні форми кисню) [29].

Неіонізуюче випромінювання. Останнім часом велику увагу приділяють неіонізуючим, мало- та неінвазивним електромагнітним маніпуляціям, до яких відносять: високоінтенсивне монохромне лазерне випромінювання [30], монохроматичне і поліхроматичне випромінювання [31, 32], інфрачервоне випромінювання [33, 34], ультрависокочастотне електромагнітне випромінювання [35, 36], НВЧ випромінювання [37, 38], ультразвук [39-41], неіонізуюче випромінювання, що генерується пульсуючим електричним полем [42].

Пупьсаційне високоінтенсивне лазерне випромінювання та інші види неіонізуючого випромінювання впливають на органели, більшою мірою на мітохондрії, міняючи їх функції і запускаючи каскади реакцій, що ведуть до ПКЗ, обумовлених біомодуляцією каскадів АФК, що активують каспазні каскади, PARP-1, NF-kB та вихід $\mathrm{Ca}^{2+}$ в цитозоль [30-33, 40,41].

Визначаючи коефіцієнт варіації «подій», що ініціюють ПКЗ, віднесених до першого рівня, слід звернути увагу на надзвичайну розрізненість мішеней ініціаторів «подій», а саме на наявність доведеного впливу на всі клітинні системи, можливість пошкодження будь-яких молекул і комплексів молекул, порушення RedOx потенціалу і найголовніше, неможливість таргетного і дозованого впливу на певні одиниці життя.

Рівень взаємодії іонів. До складу клітини входить близько 70 елементів періодичної системи, причому 24 з них присутні у всіх типах клітин. На С (65\%), O (18\%), Н (10\%) i N (3\%) припадає 96 \% ваги, оскільки ці елементи є основою всіх органічних сполук [43].

Найважливіші неорганічні катіони клітини $-\mathrm{Ca}^{2+}$, $\mathrm{Na}^{+}, \mathrm{K}^{+}, \mathrm{Mg}^{2+}, \mathrm{Zn}^{2+}$; аніони - $\mathrm{Cl}^{-}, \mathrm{PO}_{4}^{3-}, \mathrm{HCO}_{3}^{-}$[11] (табл. 1).

Таблиця 1. Порівняльна характеристика внутрішньоклітинної і позаклітинної концентрації іонів типової клітини ссавця $[43,44]$

\begin{tabular}{|c|c|c|c|}
\hline & $\begin{array}{c}\text { Внутрішньоклітинна } \\
\text { концентрація, мМ }\end{array}$ & $\begin{array}{c}\text { Позаклітинна } \\
\text { концентрація, } \\
\text { мМ }\end{array}$ & Біологічна роль \\
\hline 1 & 2 & 3 & 4 \\
\hline \multicolumn{4}{|r|}{ Катіони } \\
\hline $\mathrm{Na}^{+}$ & $5-15$ & 145 & $\begin{array}{l}\text { Головний позаклітинний катіон, регулюе осмомолярність, бере } \\
\text { участь в активному трансмембранному транспорті [45-48] }\end{array}$ \\
\hline $\mathbf{K}^{+}$ & 140 & 5 & $\begin{array}{l}\text { Головний внутрішньоклітинний мікронутрієнт, регулює } \\
\text { електролітичний баланс, формує різницю потенціалу на мембрані } \\
\text { цитоплазми }[45,49]\end{array}$ \\
\hline $\mathbf{M g}^{2+}$ & 0,5 & $1-2$ & $\begin{array}{l}\text { Виконує сигнальну та каталітичну функції, активує ферменти, } \\
\text { необхідний при синтезі більше } 300 \text { ензимів, бере участь у синтезі } \\
\text { та утилізації АТФ, асоційований з синтезом ДНК і РНК, } \\
\text { необхідний для іонного транспорту, стабілізус мембрану, } \\
\text { загальний вміст у клітині } 30 \text { мМ [50-53] }\end{array}$ \\
\hline
\end{tabular}


Продовження табл. 1

\begin{tabular}{|c|c|c|c|}
\hline 1 & 2 & 3 & 4 \\
\hline $\mathrm{Ca}^{2+}$ & $10^{-4}$ & $1-2$ & $\begin{array}{l}\text { Відіграє основну роль у фізіології та біохімії клітини, відіграє } \\
\text { важливу роль в шляхах передачі сигналу, денонується в } \\
\text { мітохондріях і ЕПР [54-59] }\end{array}$ \\
\hline $\mathrm{Zn}^{2+}$ & $0,2-0,3\left[\begin{array}{lll}60 & -62\end{array}\right]$ & $\begin{array}{c}0,14-0,31 \\
{[60-62]}\end{array}$ & $\begin{array}{l}\text { Відіграє важливу роль при метаболізмі ДНК і РНК, трансдукції } \\
\text { сигналу і експресії генів, описана фізіологічна роль в } \approx 3000 \\
\text { протеїнів [62-64] }\end{array}$ \\
\hline $\mathbf{H}^{+}$ & $\begin{array}{c}7 \times 10^{-5}\left(10^{-72} \mathrm{M} \text { або }\right. \\
\text { pH 7,2) }\end{array}$ & $\begin{array}{c}4 \times 10^{-5}\left(10^{-7.4} \mathrm{M}\right. \\
\text { або } \mathrm{pH} 7,4)\end{array}$ & $\begin{array}{l}\text { Водневі зв'язки забезпечують стабільність і гнучкість } \\
\text { макромолекул, бере участь у формуванні АТФ, служить як } \\
\text { реципієнт надлишкової енергії і легкодоступного джерела енергії } \\
\text { (формування протонного градіснта) [65], Н - енергетична } \\
\text { одиниця клітини (еквівалент двох електронів) [66] }\end{array}$ \\
\hline \multicolumn{4}{|r|}{ Аніони } \\
\hline $\mathrm{CI}$ & $5-15$ & 110 & $\begin{array}{l}\text { Відповідає за осмотичну та енергетичну резистентність клітин, } \\
\text { бере участь у підтримці рН, присутній в деяких протеїнах [67-69] }\end{array}$ \\
\hline $\mathrm{PO}_{4}{ }^{3-}$ & $0,5-5[70,71]$ & $1-1,3[72]$ & $\begin{array}{l}\text { Складова частина аденозин фосфатів, ДНК і РНК, мембранних } \\
\text { фосфоліпідів, високоенергетичні зв'язки є основним запасом } \\
\text { енергії в живих системах }[73,74]\end{array}$ \\
\hline $\mathrm{HCO}_{3}$ & 12 & 29 & $\begin{array}{l}\text { Буферний компонент живих систем нормалізує } \mathrm{pH} \text {, бере участь у } \\
\text { тканинному обміні } \mathrm{CO}_{2}[68,75]\end{array}$ \\
\hline
\end{tabular}

Програмована клітинна загибель є частиною природного процесу життя живих організмів. Загибель клітини відбувається згідно 3 механізмами, закладеними у геномі. Однак ініціація даних механізмів відбувається при настанні певних умов - прояві «подій», які є тригерами програмованої клітинної загибелі. Але прояв «подій» - недостатня умова для виконання програми смерті до кінця, для цього необхідні умови, що відповідають вимогам певного етапу. Однією 3 найважливіших умов є зрушення іонного балансу в бік ініціюючих концентрацій [7678]. Побудована модель 3 використанням бази STITCH 4.0 [79] відомих і можливих взаємодій протеїнів і хімічних речовин (рис. 2). В основі даного прикладу використані іони $\mathrm{Na}^{-}$i $\mathrm{Ca}^{2+}$ : а) три рівні відомих і можливих взаємодій, в яких прямо чи опосередковано бере участь $\mathrm{Na}^{\prime}$ (в центрі); б) три рівні відомих і можливих взаємодій, в яких прямо чи опосередковано бере участь $\mathrm{Ca}^{2 !}$ (в центрі).
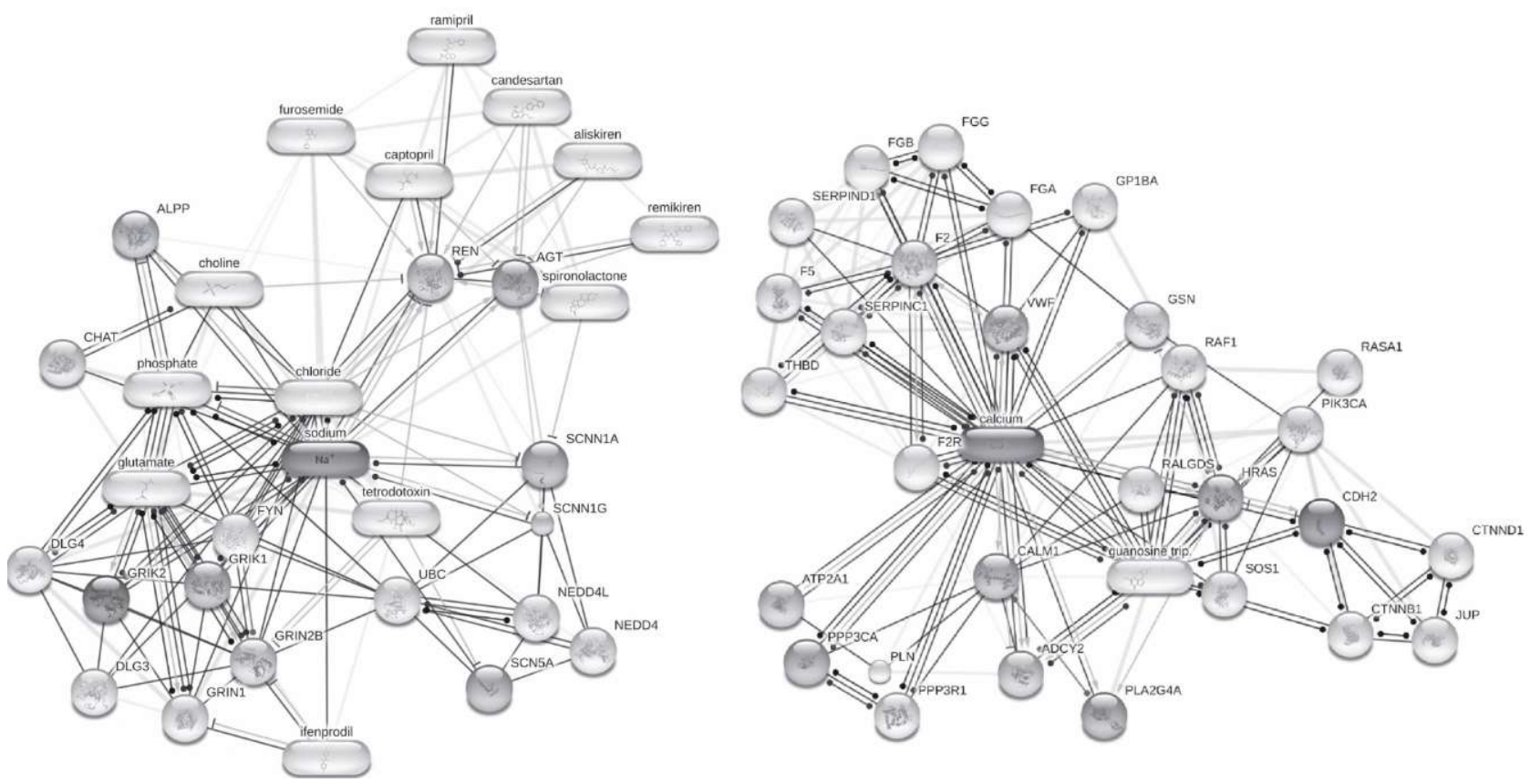

Puc. 2. Приклад моделі впливу іонів металів на компоненти цитоплазми клітини людини. 
Рівень взаємодії молекул. Найважливішою речовиною, що обумовлює життя на землі, є вода (рис. 3). Функції, які виконує вода в клітині, різноманітні, від транспортної, до структуруючого агента і носія інформації, але повністю вони не відомі [80, 81]. a)

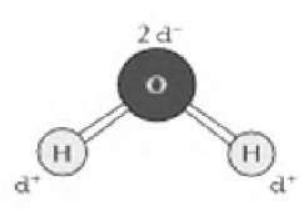

6)

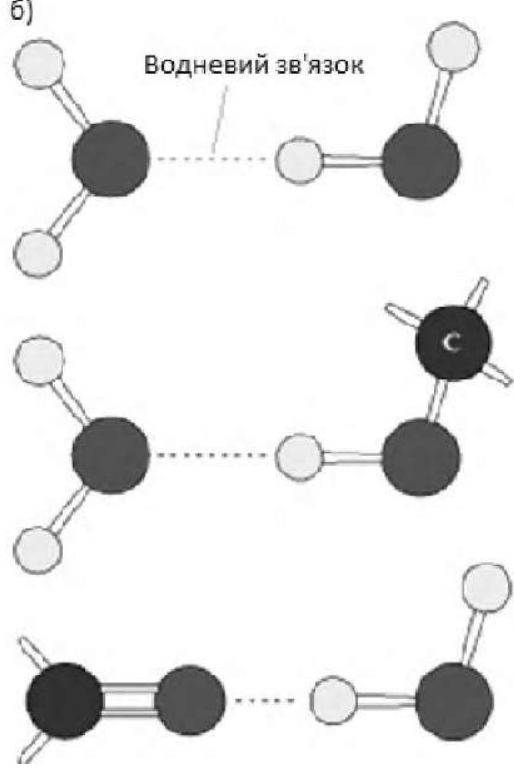

B)

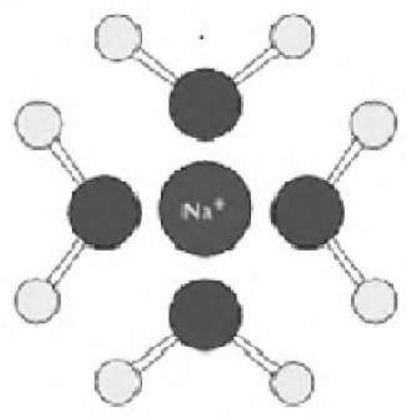

Puc. 3. Характеристики води, а) Вода - полярна молекула, яка містить негативний заряд на атомі кисню $(\delta)$ і позитивний заряд на атомі водню $\left(\delta^{+}\right)$. Завдяки своїй полярності, молекула води може формувати водневі зв'язки з іншими полярними молекулами б) або зарядженими іонами в) [82].

Також до неорганічних молекулярних компонентів клітини належать молекули газів: кисню $(\mathrm{O} 2)$, діоксиду вуглецю (CO2), монооксиду вуглецю (CO), нітриту азоту (NO) тощо.

Іншими низькомолекулярними компонентами клітини є органічні молекули, такі як: моно- і дисахариди, АТФ, амінокислоти та інші.

Вкрай важливим мономолекулярним компонентом, крім води, є АТФ, оскільки є носієм енергії у всіх організмах, включаючи людей. Рівень внутрішньоклітинного АТФ є вирішальним при визначенні шляху загибелі клітини, ПКЗ є енергозалежним процесом, що і є першопричиною збільшення кількості АТФ у клітині, яка гине, як in vitro, так і in vivo [83, 84].

Рівень взаємодії макромолекул. До цього рівня взаємодії належать всі макромолекулярні структури клітини, крім нуклеїнових кислот, які ми відносимо до рівня зберігання та реалізації генетичної інформації (генетичний базис). Природа взаємодії макромолекул вкрай складна для сприйняття, тому ланцюги управління і передачі сигналу спрощують.

Сучасні моделі описують білково-білкові взаємодії, передачі сигналу клітинної загибелі, як лінійний процес з точками біфуркацій, маючи на увазі на- явність достатніх умов для реалізації процесу передачі сигналу. Це наближення знижує достовірність моделі і не враховує варіативність умов біосинтезу білка, фізичних і хімічних факторів реакційного об'єму $[85,86]$. В основі таких моделей лежить ідентифікація критичних біомолекул процесу ПКЗ для наступної їх модифікації.

Найбільш значущим методом використання даних моделей є побудова багатовимірної регресійної моделі $з$ параметрами «активація-інгібування», але існує межа використання даних моделей, який описується «критерієм доцільності» проходження сигналу до кінця.

Використання даних моделей дозволить у майбутньому зрозуміти і оцінити ймовірність проходження будь-якого сигналу, регульованого білковими ланцюгами передачі. Існують труднощі в ідентифікації біомолекул-тригерів, здатних до ініціації сигнального шляху, що призводить до ПКЗ. Можливим напрямом даних досліджень є визначення видоспецифічних макромолекулярних структур клітин, котрі беруть участь в ланцюгах передачі сигналу ПКЗ. Дослідження саме видоспецифічних протеїнів або протеїнів, які не зустрічаються в «древніх» організмах, дозволить впливати на процес ПКЗ, оскільки такі 
молекули, 3 великою ймовірністю, не мають складних механізмів активації та інгібування.

Важливим обмежувальним фактором моделювання білково-білкових каскадів передачі сигналу є умови проходження ланки каскаду, що визначається вищими і нижчими рівнями організації виникнення «події» настання ПКЗ.

Рівень взаємодії надмолекулярних комплексів. У рамках нашої концепції до надмолекулярних комплексів належать складні білкові конгломерати, які можуть складатися 3 десятків різних молекул і

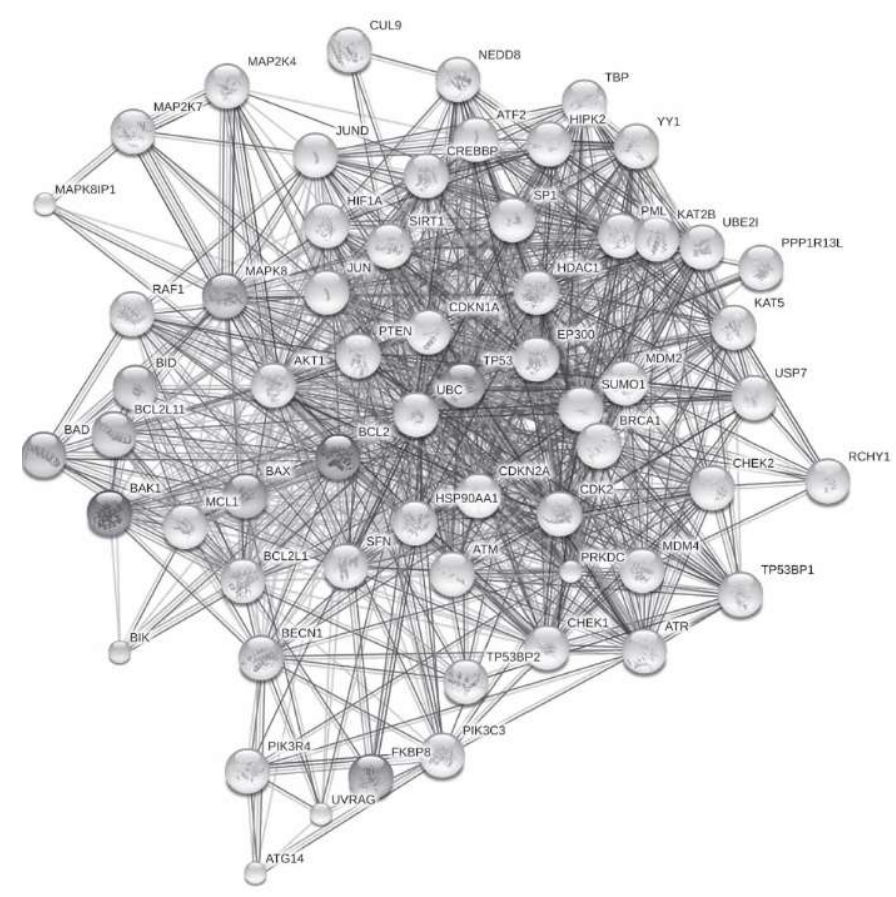

зіставні за розмірами з рибосомами (рис. 4). На жаль, роль багатьох надмолекулярних комплексів клітини, а особливо тих, що беруть участь або є ланкою у процесі передачі сигналу ПКЗ, на даний час не з'ясована. Прикладом може слугувати комплекс MRN (MRE11-RAD50-NBS1), котрий активує ATM (Ataxia-telangiectasia mutated), яка ініціює сигнальний шлях ПКЗ [88], або активація CAD DNAse яка в нормальному стані зв'язана з DFF і знаходиться в цитоплазматичних «танках» [89], що призводить до експрессії генів, відповідальних за ПКЗ.

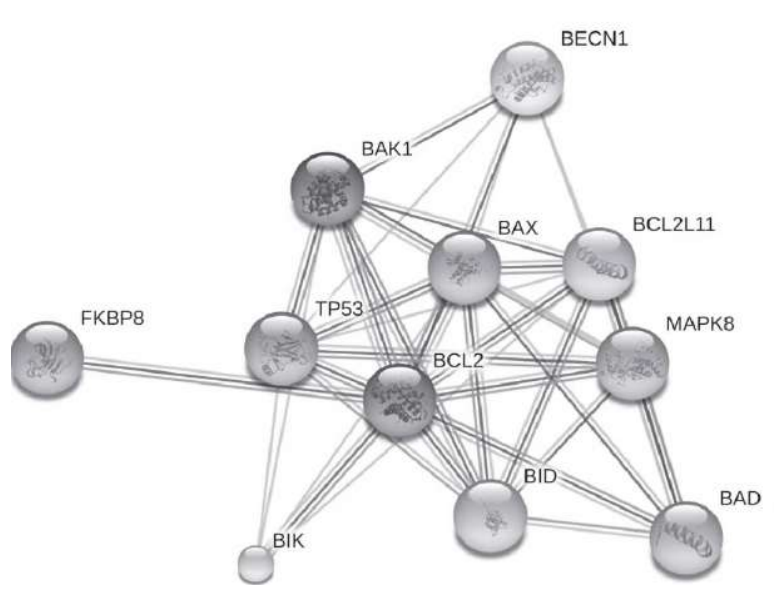

Puc. 4. Приклад лінійної моделі з точками біфуркації, модель побудована з використанням бази STRING відомих і можливих білок-білкових взаємодій [87], в основі цього прикладу використаний інгібітор ПКЗ

білок Вc1-2: а) шість рівнів білково-білкової взаємодії відомих і можливих; б) пряма білково-білкова взаємодія.

Крім цього, існує безліч надмолекулярних структур з відомими або частково відомими функціями, які беруть участь в каскадах передачі сигналу ПКЗ, такі як мембранні рецептори (FAS, TNFR, TRAILR1, TRAIL-R2, NGF) [90], іонообмінні канали, трансмембранні комплекси тощо.

TNF - цитокін, що виробляється переважно макрофагами і $є$ позаклітинним медіатором апоптозу. Більшість клітин людського організму містять два рецептори TNF:TNF-R1 iTNF-R2. Приєднання TNF до TNF-R1 активує сигнальний шлях, що веде до активації каспаз через проміжні мембранні білки надмолекулярного комплекс\}' TRADD i FADD, що, в свою черг ', призводить до утворення надмолекулярної структури апоптосоми. Існує ряд інгібіторів сигналу, яким проходить зазначеним шляхом, таких як cIAPI/2, котрий приєднується до TRAF2 тощо. При цьому існує каспазонезалежний шлях проходження сигналу ПКЗ [91, 92].

Генетичний базис. До цього рівня ми віднесли нуклеїнові кислоти, які є основними носіями інформації про структури і функції клітини.

Координація передачі сигналу по різних шляхах регулюється інформацією, закладеною в безлічі варіацій генетичних програм. Мутації в деяких генах, які беруть участь у ПКЗ на різних рівнях, ідентифікуються як «події», що обумовлюють розвиток захворювань людини. Дефект трансмембранного TNF рецептора 1 (TNF-R1) призводить до розвитку сімейного синдрому періодичної лихоманки. Мутації в 
гомологах рецептора Fas (Аро-1) виявляються при злоякісних лімфомах, солідних пухлинах та ін. Мутації в FAS лігандах, індукують ПКЗ приєднанням до FAS, описані у хворих на системний червоний вовчак та лімфоаденопатії. У пацієнтів із злоякісними новоутвореннями виявляли мутації в генах, що кодують р53, ефектор пошкодження ДІж, тригер ПКЗ, і Вах протеїн, проапоптотична молекула, яка ініціює порушення цілісності мембрани мітохондрій і безліч інших мутацій, котрі ініціюють ПКЗ та скасовують сигнальний шлях [93].

Важливим фактором впливу на виникнення «подій» на цьому рівні є наявність патогенної чужорідної генетичної інформації (вірусна ДІЖ). При вбудовуванні чужорідної вірусної ДІЖ в ДІЖ реципієнта відбувається перепрограмування систем синтезу, що і призводить до серйозних порушень функцій клітини і ПКЗ [94].

Таким чином, хоча геном людини і розшифрований [95], але ясності в процеси життя, функціонування та смерті клітини це не додало. Актуальним залишається і питання про можливість корекції на рівні генетичної інформації. Проводяться дослідження в галузі біотехнологій спрямованої трансформації живих організмів 3 метою отримання рекомбінантних препаратів, генномодифікованих організмів та ін. Існує і природний шлях модифікації генетичної інформації, крім фізико-хімічних факторів, такі як вірусні ДІЖ, котрі можуть знаходиться в латентному стані впродовж усього життя реципієнта [94].

В рамках системних досліджень виникнення «подій» наданому рівні використовується більшість методів системної біології, таких як повногеномне секвенування, епігенетичні, повногеномні дослідження експресії генів, вивчення факторів корекції. Зазначені методи дають можливість накопичувати колосальні обсяги даних, що формує переважну кількість інформації після математичної обробки результатів дослідження.

Рівень взаємодії структурних елементів клітини. Інформації, що клітинні структурні елементи можуть формувати «події», котрі призводять до ініціації програми ПКЗ, на даний момент немає, також немає інформації щодо безпосередньої участі структурних елементів в прямій передачі сигналів ПКЗ. Проте цитоскелет, центросома та ін., це структурні елементи каркасу клітини, що виконують функції транспортного середовища та впорядкування процесів, котрі перебігають в клітинах та беруть активну участь у процесах, що призводять до наступу ПКЗ. Було показано що каспази, такі як каспаза-3, задіяні на фазах екзекуції клітини, впливають на цитоскелет. При цьому спостерігаються морфологічні зміни клітини, такі як скоротливі рухи i блеббінг цитоплазматичної мембрани, конденсація хроматину, розпад ядра, фрагментація клітин 3 наступним фагоцитозом [96].

Проведені дослідження показали, що центросома, а точніше комплекс, до якого входять центросома, центріолі та сполучні філаменти, необхідні при виконанні ПКЗ. їх функція полягала у створенні умов проходження і «координації процесів» ПКЗ виконуючи функцію «мозку-клітини» [97].

Одним 3 найважливіших структурних елементів клітини є цитозоль, яка є реакційним середовищем передачі сигналу і структурою, що підтримує форму та об'єм клітини [30].

Таким чином, порушення цілісності або функціонування транспортного середовища, є «подією», що ініціює каскад реакцій ПКЗ [98].

Рівень взаємодії макроструктур клітини. Найважливішими структурами клітини, в яких виникають «події», що формують сигнал ПКЗ є: ядро [99], цитоплазматична мембрана [100], ендоплазматичний ретикупум [101], мітохондрія [102], комплекс Гольджі [103].

Ядро містить генетичну інформацію і здійснює функції зберігання, передачі та реалізації спадкової інформації із забезпеченням синтезу білка. Основні «події», що призводять до формування сигналу ПКЗ, формуються в генетичному базисі, але при цьому існує ряд «подій», котрі належать іншим рівням організації формування сигнальних шляхів.

Цитоплазматична мембрана опосередковано або прямо пов'язана з усіма елементами клітини. Через неї відбувається транспорт іонів, поживних речовин і відходів, в неї вбудовані білкові комплекси (надмолекулярні структури), рецептори, канали міжклітинної взаємодії (конексони) та ін. Таким чином, мембрана є і бар'єром, і сполучною ланкою з оточуючим середовищем, також мембрана є середовищем передачі сигналу, як в зовнішнє середовище, так і всередину клітини.

Мітохондрії є вмістилищем двох елементів сигнального шляху ПКЗ, а саме $\mathrm{Ca}^{2+}$ і цитохрому C, які $\epsilon$ ефекторами формування апоптосоми [104].

Таким чином, макроструктури клітини $є$ середовищем формування «подій», що ініціюють ПКЗ, але при цьому взаємодія відбувається на більш нижчих рівнях організації передачі сигналу.

Рівень міжклітинної взаємодії. Усередині організму гомологічні клітини формують конгломерати, тканини з загальним внутрішнім середовищем, що 
забезпечується за допомогою міжклітинних містків, коннексонів тощо. Також клітини взаємодіють між собою за допомогою рецепторів, а на відстані - за допомогою сигнальних молекул. Сигнал ПКЗ на цьому рівні, як правило, формується як відповідь оточуючого середовища на зміни, що відбулися з клітиною. При цьому існує можливість формування «події» міжклітинної природи не тільки ініціюючого ПКЗ характеру, а й формування умов проходження сигналу до кінця [105, 106]

Результати та їх обговорення. Виходячи з описаного можна сформулювати завдання для подальших досліджень:

1. Виявлення стійких міжрівневих взаємодій.

2. Визначення меж формування сигналу, що призводить до настання програмованої клітинної загибелі.

3. Систематизація даних про «події»-тригери ПКЗ, що формують умови проходження сигналу до кінця.

4. Математичний опис процесів виникнення «події» на кожному окремому рівні.

5. Визначення «критерію доцільності», як показника виконання програми загибелі клітини до кінця.

6. Створення і використання математичних моделей реалізації передачі інформації про виникнення «події» $з$ одного рівня клітинної організації на рівень реалізації програми клітинної загибелі.

Виконання поставлених завдань дозволить розширити знання про клітину, сигнальну трансдукцію i способи управління сигнальними системами, що $є$ ключемдо формування теорії та способів спрямованого клітинного програмування без втручання в генетичну інформацію.

Велика частина сучасних досліджень присвячена виникненню «подій» на рівнях вище молекулярного, що, в свою чергу, визначає формування математичних комплексів і моделей при вивченні процесів ПКЗ. Основою рівнів вище молекулярного є біфуркаційна взаємодія, тобто проходить сигнал далі чи обривається. Також для цих рівнів властива множинність шляхів проходження сигналу і присутність певних точок сходження сигналів та наявність складних комплексів умов активації, що є умовою передачі сигналу.

Вважаємо за можливе розглядати теорію «тригерних взаємодій» для формування сигналу, здатного, 3 великою ймовірністю, призвести до смерті клітини. При цьому також пропонується використання теорії формування «подій» на певному, досить низькому рівні організації в клітині. Вони можуть мати критичний характер. Зауважимо, що антагоністів «учас- ників» передачі сигналу набагато менше і шляхи проходження сигналу менш варіативні. Останнє i формує умови проходження сигналу до кінця.

Висновки. 1. Проведені дослідження відображають зростаючий інтерес дослідників усього світу до проблем формування та передачі сигналу програмованої загибелі в клітині, а також способів управління.

2. Формалізована схема рівнів генерування і передачі сигналу програмованої клітинної загибелі розширює уявлення про середовище, «події», способи передачі і «обриву», а також дозволяє визначити вектори розвитку експериментальних досліджень.

3. Визначено, що каскад реакцій, котрий призводить до ПКЗ, може бути «подієво» ініційованим на будь-якому рівні, але при цьому для кожного рівня існує своя «межа» розвитку і формування стійкого сигналу ПКЗ, що визначається умовами активації певних учасників ланцюга. Також висловлено припущення, котре непрямо підтверджується існуючими дослідженнями, про існування «тригерів» ПКЗ, активація яких забезпечує проходження сигналу до кінця, та/або наявність речовин в «тригерних концентраціях», що є умовою необриву каскаду без активації «тригерів».

4. Виявлено, що передача сигналу між рівнями здійснюється за шляхом, що описується критерієм «доцільності», залежним від умов і часу виникнення «події» ініціюючого каскад реакцій ПКЗ. Важливою умовою передачі сигналу є формування «енергонасичених» активаційних зон, що пов'язано 3 абсолютною енергозалежністю процесу ПКЗ.

5. Виявлено біфуркаційну природу каскадів i відсутність строгих схем передачі сигналу між рівнями, що забезпечує множинність шляхів проходження і обриву сигналу, а також сприяє дослідженню шляхів управління ПКЗ. При цьому на всіх рівнях організації виявляються компоненти, присутні практично у всіх схемах проходження сигналу ПКЗ.

6. Показано, що «події», характерні для рівнів 3 меншою організацією, призводять до ініціації каскаду ПКЗ з меншим ступенем варіабельності, що пов'язано з меншим числом промоутерів i, відповідно, меншим числом інгібіторів. Також визначено безпосередню участь елементарних компонентів, що відносяться нами до рівнів з низькою організацією, у формуванні та передачі сигналу на рівнях 3 більшою організацією.

7. Одним із способів виявлення та управління активного каскаду ПКЗ пропонується контролювання концентрації промоутерів (наприклад $\mathrm{Ca}^{2+}$ ) i інгібіторів (наприклад $\mathrm{K}^{+}$). 


\section{Література}

1. Overlapping genes: a new strategy of thermophilic stress tolerance in prokaryotes / D. Saha, A. Panda, S. Podder, T. C. Ghosh//Extremophiles: Life Under Extreme Conditions. - 2015. - Vol. 19, No. 2. - P. 345-353.

2. Temperature and ph control on lipid composition of silica sinters from diverse hot springs in the taupo volcanic zone, new Zealand / G. Kaur, B. W. Mountain, M. B. Stott [et al.] / / Extremophiles: Life Under Extreme Conditions. - 2015. Vol. 19, No. 2.-P. 327-344.

3. Efficacy in microbial sterilization of pulsed magnetic field treatment: international journal of food engineering / .

4. Kurtti T. J. Influence of physical factors on the growth of insect cells / T. J. Kurtti, S. P. S. Chaudhary, M. A. Brooks // In Vitro.- 1974.-Vol. 10,No. 3-4.-P. 149-156.

5. Grahl T. Killing of micro organisms by pulsed electric fields / T. Grahl, H. Markl // Applied Microbiology and Biotechnology. - 1996. - Vol. 45, No. 1-2. - P. 148-157.

6. Microbial activity at gigapascal pressures / A. Shanna, J. H. Scott, G. D. Cody [et al.] // Science (NewYork, N.Y.). 2002. - Vol. 295, No. 5559. - P. 1514-1516.

7. Witkin E. M. Time, temperature, and protein synthesis: a study ofultraviolet-inducedmutationinbacteria/E. M. Witkin // Cold Spring Harbor Symposia on Quantitative Biology. 1956.-Vol. 21.-P. 123-140.

8. Programmed cell death (pcd). apoptosis, autophagic pcd, or others? /W. Bursch,A. Ellinger, C. Gerner [et al.] //Annals of the New York Academy of Sciences. - 2000. - Vol. 926. P. $1-12$.

9. Elmore S. Apoptosis: a review of programmed cell death/ S. Elmore // Toxicologic pathology. - 2007. - Vol. 35, No. 4. -P. 495-516.

10. Mazzarello P. Aunifying concept: the history of cell theory / P. Mazzarello //Nature Cell Biology. - 1999. -Vol. 1,No. 1. -P. 13-15.

11. Molecular cell biology/H. Lodish,A. Berk S. L. Zipursky [et al.]. - W. H. Freeman, 2000. - ISBN 0-7167-3136-3.

12. Quality assessment of the human genome sequence / J. Schmutz, J. Wheeler, J. Grimwood [et al.] //Nature.-2004. - Vol. 429, No. 6990. - P. 365-368.

13. Ham D. The sihcon that moves and feels small living things / D. Ham, R. M. Westervelt // IEEE Solid-State Circuits Society Newsletter. - 2007. - Vol. 12, No. 4. - P. 4-9.

14. Methods for comparing data across differently designed agronomic studies: examples of different meta-analysis methods used to compare relative composition of plant foods grown using organic or conventional production methods and a protocol for a systematic review/K. Brandt, D. SrednickaTober, M. Baranski [et al.] // Journal of Agricultural and Food Chemistry. - 2013. - Vol. 61, No. 30. - P. 7173-7180.

15. Writing@csu [Електронний pecypc] http:// writing, colostate.edu.

16. Mello R. A. Collocation analysis: a method for conceptualizing and understanding narrative data $/ \mathrm{R}$. A. Mello // QuaUtative research. - 2002. - Vol. 2, No. 2. - P. 231-243.
17. Мінцер О. П. Щодо межі доцільності використання поняття/ О. П. Мінцер, К. М. Ігрунова//Медична інформатика та інженерія. - 2014. - No. 4. - Р. $14-22$.

18. Cosmic ray [Електронний pecypc] https:// e n.wikipedia.org/w/index.php?title= Cosmic ray\&oldid $=650931064$.

19. Ionizing radiation [Електронний pecypc] http:// e n.wikipedia.org/w/index.php?title= Ionizing radiation\&oldid $=653525197$.

20. B. Sc E. R. M. A. Viii. uranium radiation and the electrical conduction produced by it / E. R. M. A. B. Sc// Philosophical Magazine Series 5. - 1899. - Vol. 47, No. 284. - P. 109-163. 21. STAR Collaboration Observation ofthe antimatter helium4 nucleus / STAR Collaboration//Nature. - 2011. - Vol. 473, No. 7347.-P. 353-356.

22. Adriani O. The discovery of geomagnetically trapped cosmic ray antiprotons / O. Adriani, G. C. Barbarino, G. A. Bazilevskaya[et al.] // The Astrophysical Journal. - 2011. Vol. 736, No. 1.-P.L1.

23. Hodgkins P. S. The severity of alpha-particle-induced dna damage is revealed by exposure to cell-free extracts / P. S. Hodgkins, P. O'Neil, D. Stevens, M. P. Fairman//Radiation Research. - 1996. - Vol. 146, No. 6. - P. 660-667.

24. Lehnert B. E. Anew mechanism for dna alterations induced by alpha particles such as those emitted by radon and radon progeny / B. E. Lehnert, E. H. Goodwin // Enviromnental Health Perspectives. - 1997. - Vol. 105 Suppl 5. - P. 10951101.

25. Feinendegen L. E. Evidence for beneficial low level radiation effects and radiation honnesis / L. E. Feinendegen/ /The British Journal of Radiology. - 2005.-Vol. 78,No. 925. - P. 3-7.

26. Vaiserman A. M. Radiation honnesis: historical perspective and implications for low-dose cancer risk assessment / A. M. Vaiserman // Dose-Response. - 2010. Vol. 8,No. 2.-P. 172-191.

27. Who I ionizing radiation, health effects and protective measures [Електронний pecypc] http://en.wikipedia.Org/w/ index.php?title=Ionizing radiation\&oldid $=653525197$

28. Ionizing radiation induces apoptotic signal through protein kinase сд (delta) and survival signal through akt and cyclicnucleotide response element-binding protein (creb) in jurkat t cells / A. Cataldi, V. D. Giacomo, M. Rapino [et al.] // The Biological Bulletin. - 2009. - Vol. 217, No. 2. - P. 202-212. 29. Watters D. Molecular mechanisms of ionizing radiationinduced apoptosis / D. Watters // Immunology and Cell Biology. - 1999. - Vol. 77, No. 3. - P. 263-271.

30. Yoon J. Cytosolic irradiation of femtosecond laser induces mitochondria-dependent apoptosis-like cell death via intrinsic reactive oxygen cascades / J. Yoon, S. Ryu, S. Lee, C. Choi / / Scientific Reports. - 2015. - Vol. 5.

31. Blue light induced apoptosis in rat retina / J. Wu, S. Seregard, B. Spangberg [et al.] // Eye (London, England). - 1999. - Vol. 13 (Pt 4). - P. 577-583. 
32. Light-induced apoptosis in the rat retina in vivo/ C. E. Reme, M. Weller, P. Szczesny [et al.] // Degenerative Diseases of the Retina / R. E. Anderson, M. M. LaVail, J. G. Hollyfield. - Springer US, 1995. - P. 19-25.

33. Near-infrared light via light-emitting diode treatment is therapeutic against rotenone- and $\mathrm{mpp}+$-induced neurotoxicity / H. L. Liang, H. T. Whelan, J. T. Eells, M. T. Wong-Riley // Neuroscience. - 2008. - Vol. 153, No. 4. - P. 963-974.

34. Jantschitsch C. Infrared radiation does not enhance the frequency of ultraviolet radiation-induced skin tumors, but their growth behaviour in mice / C. Jantschitsch, M. Weichenthal, A. Maeda [et al.] // Experimental Dermatology. - 2011. - Vol. 20, No. 4. - P. 346-350.

35. Vojisavljevic V. Low intensity microwave radiation as modulator of the 1-lactate dehydrogenase activity / V. Vojisavljevic, E. Pirogova, I. Cosic//Medical \& Biological Engineering \& Computing. -2011. - Vol. 49, No. 7. - P. 793 799.

36. Local exposure of $849 \mathrm{mhzand} 1763$ mhzradiofrequency radiation to mouse heads does not induce cell death or cell proliferation in brain / T.-H. Kim, T.-Q. Huang, J.-J. Jang [et al.] // Experimental \& Molecular Medicine. - 2008. -Vol. 40, No. 3,-P. 294-303.

37. Xihai Li H. Y Millimeter wave radiation induces apoptosis via affecting the ratio of bax/bcl-2 in sw1353 human chondrosarcoma cells / H. Y. Xihai Li // Oncology reports. 2011. - Vol. 27, No. 3. - P. 664-72.

38. Teppone M. Extremely high-frequency therapy in oncology / M. Teppone, R. Avakyan // Journal of Alternative and Complementary Medicine (New York, N.Y.). - 2010. Vol. 16, No. 11.-P. 1211-1216.

39. Enhancement of ultrasound-induced apoptosis and cell lysis by echo-contrast agents / L. B. Feril, T. Kondo, Q.L. Zhao [et al.] // Ultrasound in Medicine \& Biology. - 2003. -Vol. 29,No. 2.-P. 331-337.

40. Feng Y Bioeffects of low-intensity ultrasound in vitro: apoptosis, protein profile alteration, and potential molecular mechanism/Y. Feng, Z. Tian, M. Wan// Journal of Ultrasound in Medicine: Official Journal of the American Institute of Ultrasound in Medicine. - 2010. - Vol. 29, No. 6. - P. 963 974.

41. Tang W. Potential mechanism in sonodynamic therapy and focused ultrasound induced apoptosis in sarcoma 180 cells in vitro / W. Tang, Q. Liu, X. Wang [et al.] // Ultrasonics. 2009. - Vol. 49, No. 8. - P. 786-793.

42. Beebe S. J. Non-ionizing radiation generated by nanosecond pulsed electric fields (nspefs) induce apoptosis in cancer in vivo / S. J. Beebe, X. Chen, J. Kolb, K. H. Schoenbach. - 2008. - 1-1 p.

43. Molecular biology of the cell / B. Alberts, A. Johnson, J. Lewis [et al.]. - Garland Science, 2002. - ISBN 0-81533218-1; 0-8153-4072-9.

44. Essential cell biology, fourth edition/B. Alberts, D. Bray, K. Hopkin [et al.]. - Garland Science, 2013. - ISBN 9781317806271.
45. Clausen M. J. V. Sodium/potassium homeostasis in the cell/M. J. V. Clausen, H. Poulsen//Metallomics and the Cell / L. Band. - Springer Netherlands, 2013. - P. 41-67.

46. Changes in intracellular sodium, chlorine, and potassium concentrations in staurosporine-induced apoptosis / F. Arrebola, S. Zabiti, F. J. Canizares [et al.] // Journal of Cellular Physiology. - 2005. - Vol. 204, No. 2. - P. 500-507. 47. Amethod for estimating intracellular sodium concentration and extracellular volume fraction in brain in vivo using sodium magnetic resonance imaging / G. Madelin, R. Kline, R. Walvick, R. R. Regatte // Scientific Reports. - 2014. Vol. 4.

48. Geleijnse J. M. Impact of dietary and lifestyle factors on the prevalence of hypertension in western populations / J. M. Geleijnse, F. J. Кок, D. E. Grobbee// European Journal of Public Health. - 2004. - Vol. 14, No. 3. - P. 235-239.

49. Hellgren M. A comparison between two prokaryotic potassium channels (kirbacl.l and kcsa) in a molecular dynamics (md) simulation study / M. Hellgren, L. Sandberg, O. Edhohn//Biophysical Chemistry.-2006.-Vol. 120, No. 1. - P. 1-9.

50. Romani A. M. P. Magnesium in health and disease / A. M. P. Romani//Interrelations between Essential Metal Ions and Human Diseases / A. Sigel, H. Sigel, R. K. O. Sigel. Springer Netherlands, 2013. - P. 49-79.

51. Spectrochemical analysis of sodium, potassium, calcium, magnesium, copper, and zinc in normal human erythrocytes / L. S. Valberg, J. M. Holt, E. Paulson, J. Szivek//The Journal of Clinical Investigation. - 1965. - Vol. 44. - P. 379-389.

52. Improvement of neurobehavioral disorders in children supplemented with magnesium-vitamin b6. i. attention deficit hyperactivity disorders / M. Mousain-Bosc, M. Roche, A. Polge [et al.] // Magnesium Research: Official Organ of the International Society for the Development of Research on Magnesium. - 2006. - Vol. 19, No. 1. - P. 46-52.

53. Wu W. Surface charge-mediated effects of mg on к flux across the chloroplast envelope are associated with regulation of stromal ph and photosynthesis / W. Wu, J. Peters, G. A. Berkowitz // Plant Physiology. - 1991. - Vol. 97, No. 2. -P. 580-587.

54. Berridge M. J. Calcium signalling: dynamics, homeostasis and remodelling / M. J. Berridge, M. D. Bootman, H. L. Roderick // Nature Reviews Molecular Cell Biology. 2003. - Vol. 4, No. 7. - P. 517-529.

55. Calcium-dependent intracellular signal pathways in primary cultured adipocytes and ank 3 gene variation in patients with bipolar disorder and healthy controls / A. Hayashi, K. Le Gal, K. Sodersten [et al.] // Molecular Psychiatry. 2014.

56. Pml regulates apoptosis at endoplasmic reticulum by modulating calcium release / C. Giorgi, K. Ito, H.-K. Lin [et al.]//Science.-2010.-Vol. 330,No. 6008.-P. 1247-1251. 57. Calcium and apoptosis: er-mitochondria $\mathrm{Ca} 2+$ transfer in the control of apoptosis / P. Pinton, C. Giorgi, R. Siviero [et al.] // Oncogene. - 2008. - Vol. 27, No. 50. - P. 6407-6418. 
58. Calcium-activated $\mathrm{raf} / \mathrm{mek} / \mathrm{erk}$ signaling pathway mediates p53-dependent apoptosis and is abrogated by ab-crystallin through inhibition of ras activation / D. W.-C. Li, J.-P. Liu, Y.-W. Mao [et al.] // Molecular biology of the cell. - 2005. Vol. 16, No. 9. - P. 4437-4453.

59. Intracellular calcium homeostasis and signaling / M. Brini, T. Cali, D. Ottolini, E. Carafoli // Metallomics and the Cell / L. Band. - Springer Netherlands, 2013. - P. 119-168.

60. Maret W. Analyzing free zinc(ii) ion concentrations in cell biology with fluorescent chelating molecules / W. Maret //Metallomics: IntegratedBiometal Science.-2015.-Vol. 7, No. 2.- P. 202-211.

61. Plum L. M. The essential toxin: impact of zinc on human health/L. M. Plum, L. Rink, H. Haase//International Journal of Environmental Research and PubUc Health. - 2010. - Vol. 7, No. 4.-P. 1342-1365.

62. Maret W. Zinc and human disease / W. Maret// Interrelations between Essential Metal Ions and Human Diseases / A. Sigel, H. Sigel, R. K. O. Sigel. - Springer Netherlands, 2013. - P. 389-414.

63. Prasad A. S. Zinc in human health: effect of zinc on immune cells / A. S. Prasad // Molecular Medicine (Cambridge, Mass.). - 2008. - Vol. 14, No. 5-6. - P. 353 357.

64. Potential roles of zinc in the pathophysiology and treatment of major depressive disorder/W. Swardfager, N. Herrmann, R. S. Mclntyre [et al.] // Neuroscience and Biobehavioral Reviews. - 2013. - Vol. 37, No. 5. - P. 911-929.

65. Wackett L. P. Microbial genomics and the periodic table / L. P. Wackett, A. G. Dodge, L. B. M. Ellis // Applied and Environmental Microbiology. - 2004. - Vol. 70, No. 2. P. 647-655.

66. Hoehler T. M. Biological energy requirements as quantitative boundary conditions for life in the subsurface / T. M. Hoehler//Geobiology.-2004.-Vol. 2,No. 4.-P. $205-$ 215.

67. Carugo O. Buried chloride stereochemistry in the protein data bank / O. Carugo // BMC Structural Biology. - 2014. Vol. 14,No. 1. - P. 19.

68. Bonar P. T. Plasma membrane cl-/hco3-exchangers: structure, mechanism and physiology/P. T. Bonar, J. R. Casey // Channels. - 2008. - Vol. 2, No. 5. - P. 337-345.

69. Three dimensional structure of porcine pancreatic alpha-amylase at 2.9 a resolution, role of calcium in structure and activity / G. Buisson, E. Duee, R. Haser, F. Payan//TheEMBOjournal. - 1987.-Vol. 6, No. 13,P. 3909-3916.

70. Bergwitz C. Phosphate sensing/C. Bergwitz, H. Juppner //Advances in chronic kidney disease.-2011.-Vol. 18, No. 2. -P. 132-144.

71. A study of intracellular orthophosphate concentration in human muscle and erythrocytes by 3 ip nuclear magnetic resonance spectroscopy and selective chemical assay / A. Bevington, K. I. Mundy, A. J. Yates [et al.] // Clinical Science (London, England: 1979). - 1986. - Vol. 71, No. 6. P. 729-735.
72. Marshall W. J. Clinical biochemistry: metabolic and clinical aspects / W. J. Marshall, S. K. Bangert. - Elsevier Health Sciences, 2008. - ISBN 0443101868.

73. Schmittner K.-E. Micro-enviromnental controls on biomineralization: superficial processes of apatite and calcite precipitation in quaternary soils, roussillon, fiance / K.E. Schmittner, P. Giresse // Sedimentology. - 1999. -Vol. 46, No. 3 , - P. $463^{\wedge} 176$.

74. Hirsch A. K. H. Phosphate recognition in structural biology / A. K. H. Hirsch, F. R. Fischer, F. Diederich // Angewandte Chemie (International Ed. in English). - 2007. -Vol. 46, No. 3.-P. 338-352.

75. Kaupp U. B. Cell biology, a universal bicarbonate sensor /U. B. Kaupp, I. Weyand // Science (NewYork NY.). - 2000. -Vol. 289, No. 5479. - P. 559-560.

76. Bortner C. D. A necessary role for cell shrinkage in apoptosis / C. D. Bortner, J. A. Cidlowski // Biochemical Pharmacology. - 1998. - Vol. 56, No. 12. - P. 1549-1559.

77. Lagadic-Gossmann D. Alterations of intracellular ph homeostasis in apoptosis: origins and roles / D. LagadicGossmann, L. Hue, V. Lecureur // Cell Death \& Differentiation. - 2004. - Vol. 11, No. 9. - P. 953-961.

78. Yu S. P. Ion homeostasis and apoptosis / S. P. Yu, L. M. T. Canzoniero, D. W. Choi // Current Opinion in Cell Biology. -2001. - Vol. 13, No. 4. - P. 405-411.

79. Stitch: chemical association networks [Електронний pecypc] http://stitch.embl.de/cgi/show input page.pl? Userld=JVpPznnqaB sj \&sessionId=7Rj 9WLk964bn .

80. Ho S. N. Intracellular water homeostasis and the mammalian cellular osmotic stress response / S. N. Ho // Journal of Cellular Physiology. - 2006. - Vol. 206, No. 1. P. 9-15.

81. Balasubramanian S. K. Membrane hydration correlates to cellular biophysics during freezing in mammalian cells / S. K. Balasubramanian, W. F. Wolkers, J. C. Bischof// Biochimica et Biophysica Acta (BBA) - Biomembranes. 2009. - Vol. 1788, No. 5. - P. 945-953.

82. Cooper G. M. The cell / G. M. Cooper. - Sinauer Associates, 2000. - ISBN 0-87893-106-6.

83. Apoptosis and necrosis: intracellular atp level as a detenninant for cell death modes / Published online: 10 July 1997; I doi:10.1038/sj.cdd.4400262.- 1997.-Vol. 4, No. 6. 84. Cells die with increased cytosolic atp during apoptosis: a bioluminescence study with intracellular luciferase / M. V. Zamaraeva, R. Z. Sabirov, E. Maeno [et al.] // Cell Death \& Differentiation.-2005.-Vol. 12, No. 11.-P. 1390-1397. 85. Dwyer D. J. Identification and characterization of programmed cell death markers in bacterial models / D. J. Dwyer, J. A. Winkler// Methods in Molecular Biology (Clifton, N.J.).-2013.-Vol. 1004.-P. 145-159.

86. Kristiansen M. Programmed cell death during neuronal development: the sympathetic neuron model/M. Kristiansen, J. Ham // Cell Death \& Differentiation. - 2014. - Vol. 21, No. 7. - P. 1025-1035.

87. String: functional protein association networks [Електронний ресурс] http://string-db.org/newstring cgi/ 
show inputj $>$ age.pl? UserId=BPssjFi03UYV\&sessionId $=7$ YqlbvWJPD4A.

88. Lavin M. F. Ataxia-telangiectasia: from a rare disorder to a paradigm for cell signalling and cancer/M. F. Lavin// Nature Reviews Molecular Cell Biology. - 2008. - Vol. 9, No. 10. P. 759-769.

89. The contribution of apoptosis-inducing factor, caspaseactivated dnase, and inhibitor of caspase-activated dnase to the nuclear phenotype and dna degradation during apoptosis / V. J. Yuste, I. Sanchez-Lopez, C. Sole [et al.] // Journal of Biological Chemistry.-2005.-Vol. 280, No. 42.-P. 35670 35683.

90. Sperelakis N. Cell physiology source book: essentials of membrane biophysics / N. Sperelakis. - Elsevier, 2012. ISBN 9780080574554.

91. Chen G. Tnf-rl signaling: a beautiful pathway / G. Chen, D. V. Goeddel // Science (NewYork NY.). - 2002. - Vol. 296, No. 5573.-P. 1634-1635.

92. Ihnatko R. Tnf signaling: early events and phosphorylation /R. Ihnatko, M. Kubes// General Physiology and Biophysics. - 2007. - Vol. 26, No. 3. - P. 159-167.

93. Mutations in apoptosis genes: a pathogenetic factor for human disease / L. Mullauer, P. Gruber, D. Sebinger [et al.] / / Mutation Research/Reviews in Mutation Research. - 2001. -Vol.488, No. 3.-P. 211-231.

94. Koonin E. V. The ancient virus world and evolution of cells / E. V. Koonin, T. G. Senkevich, V. V. Dolja // Biology Direct. - 2006. - Vol. 1. - P. 29.

95. Human genome project [Електронний pecypc] http:// en.wikipedia.org/w/index.php?title=Human Genome Project\&oldid $=653998083$.

96. Ndozangue-Touriguine O. Cytoskeleton and apoptosis / O. Ndozangue-Touriguine, J. Hamelin, J. Breard // Biochemical Pharmacology. - 2008. - Vol. 76, No. 1. P. 11-18.
97. Kong Q. The centrosome-centered cell-brain in apoptosis /Q. Kong//Medical Hypotheses.-2003.-Vol. 61,No. 1,P. 126-132.

98. GenescaM. Actin cytoskeleton derangement induces apoptosis in renal ischemia/reperfusion/M. Genesca,A. Sola, G. Hotter // Apoptosis: An International Journal on Programmed Cell Death. - 2006. - Vol. 11, No. 4. - P. 563 571.

99. Lecoeur H. Nuclear apoptosis detection by flow cytometry: influence of endogenous endonucleases / H. Lecoeur // Experimental Cell Research.-2002.-Vol. 277, No. 1.-P. 114.

100. Fadeel B. Plasma membrane alterations during apoptosis: role in corpse clearance / B. Fadeel // Antioxidants \& Redox Signaling. - 2004. - Vol. 6, No. 2. - P. 269-275.

101. Regulation of apoptosis by endoplasmic reticulum pathways / D. G. Breckenridge, M. Germain, J. P. Mathai [et al.] //Oncogene.-2003.-Vol. 22, No. 53.-P. 8608-8618. 102. Wang C. The role of mitochondria in apoptosis*/ C. Wang, R. J. Youle //Annual Review of Genetics. - 2009. -Vol. 43.-P. 95-118.

103. Hicks S. W. Golgi structure in stress sensing and apoptosis / S. W. Hicks, C. E. Machamer // Biochimica et Biophysica Acta (BBA) - Molecular Cell Research. - 2005. Vol. 1744, No. 3. - P. 406-414.

104. Nuclear apoptosis induced by isolated mitochondria / Z. F. Jiang, Y. Zhao, X. Hong, Z. H. Zhai // Cell Research. 2000.-Vol. 10, No. 3,-P. 221-232.

105. Intercellular bridges and apoptosis in clones of male germ cells / G. Hamer, H. L. Roepers-Gajadien, I. S. Gademan [et al.] // International Journal of Andrology. - 2003. - Vol. 26, No. 6. - P. 348-353.

106. Wang $X$. Transfer of mitochondria via tunneling nanotubes rescues apoptotic pc12 cells / X. Wang, H.-H. Gerdes//Cell Death \& Differentiation.-2015-P. 1-11. 